\title{
Leadership Behavior and Acceptance of Leaders by Subordinates: Application of Path Goal Theory in Telecom Sector
}

\author{
Sikandar Hayyat Malik, Shamsa Aziz, and Hamid Hassan
}

\begin{abstract}
This article is a part of a research study carried out for the Ph.D dissertation. one of the aspect of the research was to explore the relationship between leadership behavior and acceptance of leader by the subordinates. The moderating variables of study were situational factors i.e. subordinates' characteristics and environmental characteristics. Path-goal theory was tested in telecom industry of Pakistan by conducting research on the 60 middle and 140 lower managers of four mobile companies. Data analysis revealed significant relationship of subordinate acceptance of leader with leadership behavior and situational factor. .It was also found that leadership behavior affects subordinates' acceptance of leader and can be used as predictor of acceptance of leader. Management of the cellular companies may be benefited from the findings of this research, so there are some recommendations for them at the end of this article.
\end{abstract}

Index Terms-Path goal theory, subordinates' characteristics. environmental characteristics, leaderships' behavior, acceptance of leader.

\section{INTRODUCTION}

\section{A. What Is Leadership?}

The term leadership has different connotations to different people that create ambiguity of meaning. According to [1] this ambiguity emerges from the fact that the concept entails a multifaceted interaction among the leader, his subordinates and the particular situation

Leadership is a universal phenomenon and has been defined and studied from a wide variety of perspectives and disciplinary approaches as narrated by [2] this has resulted in different theories of leadership.

Reference [3] reported that a few years ago, fifty-four leadership experts from thirty-eight countries reached a consensus that leadership means an ability to influence, motivate and enable others in a way that they contribute towards the efficiency and accomplishment of the mission/goals of organizations which have employed them. A leader is a person who exhibits ideas, vision, values, influences others, and makes tough decisions. If a person possesses these key attributes then he can act as a leader as in [4] "leadership occurs when particular individual exerts

Manuscript received September 20, 2013; revised November 21, 2013.

Sikander Hayat Malik is with the State Bank of Pakistan Based at Karachi, Pakistan (e-mail: sikandar.malik@hotmail.com).

Shamsa Aziz is with Department of Education, International Islamic University Islamabad, Pakistan (e-mail: phd_edu@yahoo.com).

Hamid Hassan is with the Federal College of Education, Islamabad Pakistan (e-mail: phd_edu@hotmail.com). influence upon others for the achievement of goal in an organizational setting by enhancing the productivity, innovation, satisfaction, and commitment of the work force".

Sometimes leadership is seen as a process while some times as a relationship. Some scholars view it as the outcome of a set of traits/attributes, while there are others who regard it as a social process that emanates from relationships among the group. This difference in perception always results in different estimation of the leadership's character e.g. as defined in [5] leadership as the process by which ideas and a vision are developed, then living by values that support those ideas and that vision, influencing others to embrace these values in their own behaviors, and making hard decisions about human and other resources but [6] defined leadership as a relationship through which leaders influence their followers. To [7] leadership is a series of functions that have to be carried out in order for the group to be effective. Where the group's task may need to be clarified, resources may be required, occasionally the spirits of group members may need lifting, and the group's output must eventually be evaluated.

Thus leadership is the art or a process of influencing people and motivating them to work willingly and enthusiastically towards the attainment of common goals through maximum application of his/her capabilities and in this process leader facilitates progress and inspires the group to attain goals, which the organization has set for itself.

Reference [8] says that despite the fact that leadership is recognized as an important skill a mystery prevails as to what it actually is and how it can be defined.

\section{B. Effective Leaders}

When the subordinates believe in leader, Idealize him, unconditional follow him and accepts him blindly than we say he is an effective leader. Reference [9] say that the leaders that can be called effective when they are helpful to a group of people for defining their goals and finding certain ways through which these goals can be achieved

\section{Leadership Behavior}

Leadership behavior is the behavior; a leader exhibits.

\section{Path-Goal Theory of Leadership}

The Path-goal theory of leadership is widely recognized contingency approach to leadership. The concepts and terminologies used in Path-goal had already been used [10] at University of Michigan's Institute of Social Research, before it was developed and published as a theory [11], [12].

Path-goal theory of leadership is based on Vroom's expectancy theory of motivation with its concepts of expectancy, outcomes, valence and instrumentality. [13] 
“The theory was stimulated by Evan's paper in which the relationship between the Ohio State measures of leader consideration and leader initiating structure and follower perception of path-goal relationship (instrumentality and expectations) were assessed."

In 1971, House formulated a more elaborated version of the theory that included situational variables as well. The theory has been further refined and extended over the years [13]-[15].

Reference [16] believes that path-goal theory tries to elucidate the reason behind the working of contingent rewards and how these rewards effect the subordinates' satisfaction and motivation. While [8] is of the view that the re-enforcement of change in the subordinate by the leader is a prominent aspect of path-goal leadership.

The Path-goal theory states that a leader must be able to manifest four different styles of behavior which are

Directive: when leader provides specific guidelines to subordinates on how they have to perform their tasks. Further, leader sets standards of performance and provides explicit expectations of performance.

Supportive: when the leader demonstrates concern for subordinate well-being and is supportive to individuals.

Participative: when leader solicits ideas and suggestions from subordinates and invites their participation in decisions that directly affect them.

Achievement oriented: when leader sets challenging goals, emphasizes improvements in work performance, and encourages high levels of goals attainments [17]:

Leaders can affect a subordinate's performance, motivation and satisfaction in several ways, such as: by clarifying the subordinate's role as what is expected from him/her; linking rewards to the subordinate satisfactory performance; and increasing the size and value of the rewards

\section{E. Acceptance of Leader}

This concept refers to the state where subordinate complies with the directives and orders of his leader and is always ready to accept the decisions made by the leader. He is at high comfort level with his leader and feels pleased while working with him.

Participation in decision-making always increases acceptance of leader' though involving entire group requires lot of efforts and time but ensures high level of acceptance of decisions and leader also, resulting in efficient execution. The acceptance of orders by subordinates' depends upon the surrounding/situational conditions. Further, the compliance of orders is linked the extent such orders are: understood; consistent with the mission of the organization; compatible with the personal interests of the subordinates and to the extent to which subordinate is physically and mentally able to comply with them.

The effective administrative authority leads to willing rather than forced compliance. But each subordinate has a "zone of indifference" maintained by the interests of the group. Reference [18] found that the zone of acceptance increased to the extent SUBORDINATES is given autonomy.

\section{Methodology}

The population of the study consisted of the middle and lower managers working as regular employees in different companies of the telecom (cellular) industry of Pakistan

Stratified random sampling technique was used to select 60 middle managers \&140 lower managers working in Mobilink, Ufone, Telenor and Warid. (15 middle managers and 35 lower managers from each organization).

For the collection of data a number of questionnaires were used. The acceptance of leader was measured through a 10 items scale [19]. The leadership behavior was measured through a set of 20 questions: Five questions measuring directive and participative leadership behavior; seven questions measuring supportive leadership behavior; and three questions measuring achievement-oriented leadership behavior. The subordinates' and environmental characteristics were measured through a set of 45 questions with eight questions measuring task structure; nine questions measuring role ambiguity; ten questions measuring stress; five questions measuring need for achievement; four questions measuring need for autonomy; four questions measuring perception about abilities; and five questions measuring locus of control. These questions (instruments) were used in combination with general demographic questions seeking information about attributes such as age, gender, qualification, rank, salary range, experience and length of service under current supervisor for data collection.

Researcher approached the Human Resources Departments of the major cellular companies, explained the purpose of the research, with a request to provide number of regular employees on the pay roll of company and working as middle managers along with supervisors/lower managers working in their work unit whom they were directly supervising. Both technical and non-technical areas of the company were included in the study. After seeking the necessary permission from Human Resources Department/company, researcher personally approached the participants of study for the collection of data.

\section{DATA ANALYSIS}

Data collected was analyzed according to the Nine hypotheses specifically formulated for the study.

$\mathrm{H}_{01}$ : There is no significant relationship between leadership behavior and subordinates' acceptance of leader.

TABLE I: PEARSON $R$, CRITICAL VALUE, $R$-SQUARE AND PERCENT OF COMMON VARIANCE OF LEADERSHIP BEHAVIOR AND ACCEPTANCE OF

\begin{tabular}{lccccc}
\multicolumn{7}{c}{ LEADER } \\
\hline & Count & Correlation & $p$ value & $R$-Square & $\begin{array}{c}\% \\
\text { VOC }\end{array}$ \\
\hline Directive & 150 & .392 & .000 & .153 & 15.3 \\
Supportive & 152 & .370 & .000 & .136 & 13.69 \\
Participative & 152 & .200 & .013 & .040 & 04.00 \\
$\begin{array}{l}\text { Achievement } \\
\text { Oriented }\end{array}$ & 152 & .369 & .000 & .136 & 13.69 \\
\hline
\end{tabular}

The Table I exhibits the correlation coefficient between leadership behaviors and acceptance of leader. The correlation coefficients are significant so the null hypothesis 
was rejected. And it is concluded that there is a significant relationship between leadership behavior and subordinate acceptance of leader. The directive leadership behavior has strong relationship as compared to other facets of leader behavior with acceptance of leader as 15.3 percent variance in acceptance of leader is due to directive leader behavior.

$\mathrm{H}_{02}$ : There is no significant relationship between linear combination of four leadership behavior, (directive, supportive, participative and achievements-oriented) and subordinate's acceptance of leader.

The Table II shows the linear regression analysis for linear combination of four leadership behaviors (directive, participative, supportive and achievement oriented) and acceptance of leader by subordinates. It was calculated by adding the scores of four leadership behavior. The regression equation for predicting the acceptance of leader is:

Predicted acceptance of leader $=15.605+.12$ leadership behavior

The analysis shows that $16.2 \%$ variance in acceptance of leader is due to leadership behavior.

$\mathrm{H}_{03}$ : There is no significant relationship between attributes of subordinates (age, gender, qualification, rank, experience and length of service under the current supervisor) and subordinate's acceptance of leader.

The Table III indicates the regression analysis for attributes of subordinates as predictor of acceptance of leader. The analysis shows that the attributes of subordinates accounted for 3.9 percent of the variation in acceptance of leader. Since the $F$ value was not significant so the null hypothesis was accepted.

The beta values and $t$-values are all insignificant but had negative moderate correlation except for qualification and experience which have +ve correlation with the acceptance of leader.

$\mathrm{H}_{04}$ : There is no significant relationship between situational factor (task structure, role ambiguity, stress, need for autonomy, locus of control, need for achievement, \& perception about ability) and subordinates' acceptance of leader.

TABLE II: LINEAR REGRESSION ANALYSIS FOR LEADERSHIP BEHAVIOR AS PREDICTOR OF ACCEPTANCE OF LEADER

\begin{tabular}{lllllll}
\hline$t$ value & $P$ & $B$ & $F$-Ratio & $R$ & $R^{2}$ \\
\hline 9.415 & .000 & 15.605 & 29.064 & .403 & .162 \\
\hline
\end{tabular}

TABLE III: MulTIPLE REGRESSION ANALYSIS: AGE, GENDER, QUALIFICATION, RANK/DESIGNATION, EXPERIENCE, AND LENGTH OF SERVICE UNDER

\begin{tabular}{lccccccc}
\hline \multicolumn{7}{c}{ CURRENT SUPERVISOR AND ACCEPTANCE OF LEADER } \\
\hline Predictors & $\mathrm{B}$ & $t$-value & $P$ & $R$ & $F$ Ratio & Sig & $R^{2}$ \\
\hline Age & -1.854 & -1.720 & .088 & -.121 & & & \\
Gender & -.264 & -.300 & .765 & -.016 & & & \\
Qualification & .167 & .617 & .538 & .079 & & & .039 \\
Rank & -.208 & -.236 & .814 & -.021 & .726 & .651 & \\
Experience & .345 & .675 & .501 & .028 & & & \\
Service & -.262 & -.415 & .679 & -.032 & & & \\
\hline
\end{tabular}

TABLE IV: Multiple Regression ANALysis: TASK STRUCTURE, ROLE AMBIGUITY, STRESS, NEED FOR AUTONOMY, LOCUS OF CONTROL, NEED FOR ACHIEVEMENT, PERCEPTION ABOUT ABILITY AND ACCEPTANCE OF LEADER

\begin{tabular}{|c|c|c|c|c|c|c|c|}
\hline Predictors & $B$ & $t$-value & $P$ & $r$ & $F$-Ratio & Sig & $R^{2}$ \\
\hline Locus of Control & .101 & .802 & .424 & .302 & & & \\
\hline Ability & .221 & 1.667 & .098 & .370 & & & \\
\hline Task Structure & -.016 & -.192 & .848 & .192 & & & \\
\hline Role Ambiguity & .096 & 1.603 & .112 & .272 & 9.092 & .000 & .347 \\
\hline Stress & -.324 & -4.103 & .000 & -.431 & & & \\
\hline Achievement Need & .225 & 2.083 & .039 & .445 & & & \\
\hline Autonomy Need & .016 & .105 & .916 & .267 & & & \\
\hline
\end{tabular}

TABLE V: GENDER WISE DIFFERENCE REGARDING ACCEPTANCE OF LEADER

\begin{tabular}{lcccc}
\hline Gender & $N$ & Mean & $t$ & $d f$ \\
\hline Male & 105 & 24.5905 & .144 & 135 \\
Female & 32 & 24.4688 & .886 \\
\hline
\end{tabular}

TABLE VI: AGE WISE DIFFERENCE REGARDING ACCEPTANCE OF LEADER

\begin{tabular}{lcccc}
\hline Gender & $N$ & Mean & $t$ & $d f$ \\
\hline Age group(20-40) & 127 & 24.5118 & & \\
& & & .936 & 149 \\
Age group(41-60) & 24 & 25.5833 & .351 \\
\hline
\end{tabular}


The Table IV shows the results of multiple regression analysis of situational factors and subordinates acceptance of leader. The regression equation was significant so the null hypothesis was rejected. All individual situational factors had no significant relationship with subordinates' acceptance of leader except stress. Moreover, task structure and stress had negative contribution to the acceptance of leader which means that these variables increases acceptance of leader.

$\mathrm{H}_{05}$ : There is no gender wise significant difference in the acceptance of leader.

Table V shows analysis of gender difference with acceptance of leader by subordinates. The results reveal that $t$ value is not significant so the null hypothesis was accepted. It is concluded that there is no gender wise significant difference in acceptance of leader.

$\mathrm{H}_{06}$ : There is no age wise significant difference in acceptance of leader in employees.

Table VI shows analysis of age difference and acceptance of leader. The results reveal that $t$ value is not significant so the null hypothesis was accepted. It is therefore concluded that there is no age wise significant difference in the acceptance of leader.

$\mathrm{H}_{07}$ : There is no significant difference in the acceptance of leader of employees having different qualifications.

TABLE VII: DIFFERENCE REGARDING ACCEPTANCE OF LEADER OF EMPLOYEES WITH DIFFERENT QUALIFICATIONS

\begin{tabular}{lcccc}
\hline Qualifications & $N$ & $d f$ & $F$ & Significance \\
\hline B.A/B.Sc & 40 & & & \\
M.A/M.Sc & 73 & & & \\
M.Phill & 9 & 4 & 1.437 & .225 \\
PhD & 4 & & & \\
Others & 25 & & & \\
\hline
\end{tabular}

Table VII presents analysis of subordinates' acceptance of leader having different qualifications. The results reveal that $F$ value is not significant so the null hypothesis was accepted. It is therefore, concluded that there is no significant difference in the subordinates acceptance of leader having different level of qualifications.

$\mathrm{H}_{08}$ : There is no significant difference in the acceptance of leader of employees having different experiences.

TABLE VIII: DIFFERENCE REGARDING ACCEPTANCE OF LEADER OF EMPLOYEES WITH DIFFERENT EXPERIENCES

\begin{tabular}{lllll}
\hline Experiences & $N$ & $d f$ & $F$ & Significance \\
\hline$>$ 1 Year & 15 & & & \\
1-5 Years & 76 & & & \\
6-10 Years & 44 & 4 & 1.085 & .366 \\
11-20 Years & 12 & & & \\
21 -30 Years & 4 & & & \\
\hline
\end{tabular}

Table VIII shows analysis of acceptance of leader by subordinates with varying length of experience. The results reveal that $F$ value is not significant so the null hypothesis was accepted. It is therefore, concluded that there is no significant different in the acceptance of leader by subordinates with varying length of experience.
$\mathrm{H}_{09}$ : There is no significant difference in the perception of lower and middle management regarding acceptance of leader.

TABLE IX: DIFFERENCE IN PERCEPTION OF LOWER AND MIDDLE MANAGEMENT REGARDING ACCEPTANCE OF LEADER

\begin{tabular}{lcllll}
\hline \multicolumn{5}{c}{ MANAGEMENT REGARDING ACCEPTANCE OF LEADER } \\
\hline Rank & $N$ & Mean & $T$ & $d f$ & Significance \\
\hline $\begin{array}{l}\text { Lower } \\
\text { Managers }\end{array}$ & 115 & 24.3391 & -.111 & 150 & .192 \\
$\begin{array}{l}\text { Middle } \\
\text { Managers }\end{array}$ & 37 & 24.4324 & & & \\
\hline
\end{tabular}

Table IX presents analysis of difference in the perception of lower and middle managers regarding acceptance of leader. The results reveal that $t$ value is not significant so the null hypothesis was accepted. It is concluded that there is no significant difference between lower and middle management regarding acceptance of leader.

\section{FINDINGS}

1) There is a significant relationship between leadership behavior and subordinate acceptance of leader.

2) There is a significant relationship between linear combination of four leadership behaviors(directive, supportive, participative and achievements-oriented) and subordinate's acceptance of leader

3) Leadership behavior affects subordinates' acceptance of leader and can be used as predictor of acceptance of leader by the subordinates

4) There is no significant relationship between attributes of subordinates (age, gender, qualification, rank, experience and length of service under the current supervisor) and subordinate's acceptance of leader.

5) There is a significant relationship between situational factor (task structure, role ambiguity, stress, need for autonomy, locus of control, need for achievement, \& perception about ability) and subordinates' acceptance of leader

6) The regression equation for situational factors (Locus of control, ability, task structure, role ambiguity, stress, achievement need and autonomy need) and subordinates acceptance of leader was significant except stress.

7) Task structure and stress had negative contribution to the acceptance of leader which means that these variables increase acceptance of leader.

8) There is no gender wise significant difference in the acceptance of leader

9) There is no age wise significant difference in acceptance of leader among employees.

10) There is no significant difference in the acceptance of leader of employees having different qualifications

11) There is no significant difference in the acceptance of leader by employees having different experiences

12) There is no significant difference in the perception of lower and middle management regarding acceptance of leader

\section{CONCLUSIONS AND Discussion}

Path goal theory holds that depending upon subordinates' 
and task characteristics, an effective leader will use each of the four types of leader behaviors in different situations. Findings of the study concluded that leadership behavior had significant relationship with acceptance of leader. The analysis reveals that directive leader behavior has strong relationship with acceptance of leader which is in conformity with path goal theory which states that subordinates are more satisfied with directive leader behavior when task is not structured. Further highly structured tasks are less satisfying than unstructured tasks [14]. The attributes of subordinates had no significant effect on the acceptance of leader by subordinates. However, male employees had higher mean score than female employees and employees in age group (41-60) had higher mean score than those in age group (20-40). Similarly, middle managers had higher mean score as compared to lower managers on acceptance of leader. The beta values and t-values of age, gender, rank, and length of service under the current supervisor had moderate and negative correlation with acceptance of leader whereas; qualification and experience had positive correlation with acceptance of leader.

The situational factors do affect the subordinates' acceptance of leader. All the situational variables except stress had no significant relationship with subordinates' acceptance of leader. Further, situational factors: task structure and; stress had negative correlation with subordinates' acceptance of leader which means that these variables increase acceptance of leader. The path goal theory assumes that highly structured tasks are less satisfying than unstructured tasks. This study confirms this assumption because task structure was negatively related to the acceptance of leader. This study also confirms path goal prediction that when task is dissatisfying, routine or structured subordinate will be dissatisfied, as there was an inverse relationship between task structure and acceptance of leader.

Path goal theory assumes that directive leader behavior increases subordinates' acceptance of leader by clarifying roles and responsibilities, thus helping subordinates to perform their work smoothly. In this study it was found that stress had inverse relationship with acceptance of leader. It means highly stressed subordinates had greater acceptance when manager displayed directive leadership behavior.

This study concluded that directive leader behavior had most significant relationship with acceptance of leader having $15.3 \%$ variance followed by supportive and achievement oriented leader behavior having $13.69 \%$ variance in acceptance of leader. So this study confirms the assumptions of path goal theory and supports findings of studies [14], [19], [20].

\section{RECOMMENDATIONS}

As the study concluded that there is a significant relationship between leader behavior and subordinates' acceptance of leader. The situational factors also affect the subordinates' acceptance of leader. That's why there are some recommendations for the management of the cellular companies.

1) Revisit the job descriptions and work structure to avoid role ambiguity and stress
2) Try to manage the expectation of employees so that acceptance of leader can be enhanced

3) Revise the promotion policies and compensation structure which ensures the culture of performance, justice and fair play.

4) Introduce participatory management to ensure involvement of subordinates in decision making

5) Design and develop training programs to train managers on the role of situational factors (environmental and subordinate characteristics) in the organizational effectiveness and subordinates acceptance of leaders.

\section{REFERENCES}

[1] R. Kreitner and A. Kinicki, Organizational behavior, $6^{\text {th }}$ ed. New York: McGraw-Hill, 2004.

[2] G. Yukl, Leadership in Organizations, $6^{\text {th }}$ ed. Pearson Education, 2006.

[3] R. J. House, P. Hanges, M. Javidan, and P. Dorfman, Culture and Leadership, across the World: the GLOBE Book of In-depth Studies of 25 Societies, London: Routledge, 2002.

[4] G. Johns and A.M. Saks, Organizational Behavior: Understanding and Managing Life at Work, 7th ed. New York: Pearson Prentice Hall, 2007.

[5] D. Hellriegel and J.W. Slocum, Organizational behavior, $11^{\text {th }}$ ed. Thomson South-Western, 2007.

[6] H. Koontz and H. Weihrich, Essentials of management-An international perspective, $7^{\text {th }}$ ed. New Delhi: Tata McGraw Hill, 2007.

[7] S. M. Jex and T. W. Britt, Organizational Psychology: A Scientist-Practitioner Approach, 2nd ed. New York: John Wiley, 2008.

[8] W. B. Howieson, "A quantitative evaluation of the reformulated 1996 Path-Goal Theory of work unit leadership via structural equation modeling," Doctoral Dissertation, University of Edinburgh, 2008.

[9] S. McShane and T. Travaglione, Organizational Behavior on the Pacific Rim, Enhanced Ed. Boston: Mc Graw-Hill, 2005.

[10] B. S. Georgopoulous, G.M. Mahoney, and N. W. Jones, "A Path-Goal approach to productivity," Journal of Applied Psychology, vol. 41, pp. 345-353, 1957.

[11] R. J. House, "Role conflict and multiple authority in complex organizations," California Management Review, vol. 12, no. 4, pp. 53-60, Summer 1970.

[12] R. J. House, "A Path-Goal Theory of leader effectiveness," Administrative Science Quarterly, pp. 321-338, September 1971.

[13] R. J. House, "Path-Goal Theory of leadership: lessons, legacy, and a reformulated theory," Leadership Quarterly, vol. 793, pp. 323-352, 1996.

[14] R. J. House and G. Dessler, "The path-goal theory of leadership: some Post Hoc and a Priori Tests," in Contingency approaches to Leadership, J. G. Hunt and L. L. Larson, Eds. Carbondale: Southern Illinois University Press, 1974

[15] R. J. House and T. R. Mitchell, "Path-Goal Theory of leadership," Contemporary Business, vol. 3, pp. 81-98, Fall 1974.

[16] B. M. Bass and R. Bass, The Bass Handbook of Leadership: Theory Research and Managerial Applications, New York: Free Press, 2008.

[17] P. A. Muchinsky, Psychology to Work: An introduction to industrial and organizational psychology, $8^{\text {th }}$ ed. Thomson South-Western, 2006.

[18] L. R. Johnson, "An exploratory study of servant leadership, emotional intelligence and job satisfaction among high-tech employees," Doctoral Dissertation University of Phoenix, 2008.

[19] R. Nisa, "A study of relationship among college principals and their subordinate's job satisfaction and acceptance of leader- A Path-Goal approach," Unpublished doctoral dissertation, Lahore: The University of Punjab, 2003.

[20] A. D. Szilagyi and H. P. Sims, "The cross-sample stability of the supervisory behaviour description questionnaire," Journal of Applied Psychology, vol. 59, pp. 767-770, 1974.

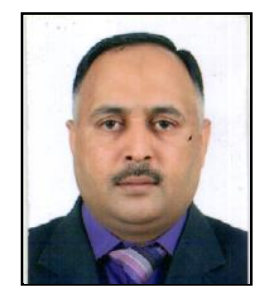

Sikandar Hayyat Malik was born in the most fertile province of Pakistan 'Punjab' on February 07,1976 . He completed his doctor of philosophy in human resource development from National University of Modern languages, Islamabad, Pakistan in 2011. Furthermore, he also did his masters in public administration (specialization in HR) and master of arts in English literature from University of the Punjab, Lahore, Pakistan in 2003 
and 2000 respectively. He graduated in science with the major subjects of Chemistry, Botany and Zoology in 1996 from University of Punjab.

Currently, he is working in one of the finest Institution of Pakistan, its Central Bank 'State Bank of Pakistan' as a senior joint director of HR Department, located in Karachi. He joined SBP in February 2007 as a joint director/ HR manager. Previously he has also worked for other prestigious organizations of the country on different key managerial positions. His endless love to literature and concerted efforts for promoting it, he is also the author of different publications.

Having the wider exposure to the corporate world Dr. Malik is associated with different renowned professional bodies like 'Society for Performance Improvement', 'the Global Organization for Humanitarian Work Psychology' and 'Management Association of Pakistan'. As one of the dynamic corporate professional, Dr. Malik has also attended seminars and conferences on different key topics like 'Innovation in Organizations, Initiative and Creativity- A dialectic perspective' held in University of Valencia, Spain in 2013.

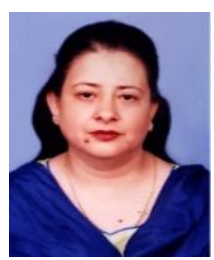

Shamsa Aziz was born in Lahore the Capital of Punjab on September 1, 1964. She completed her Ph.D. in education from the University of the Punjab, Lahore, Pakistan in 2004. Furthermore she also did her masters in political science and science education from the University of the Punjab, Lahore, Pakistan, in 1993 and 1988 respectively. She completed did her post doc. form the University of Glasgow, Glasgow, Scotland, UK under the guidance of professor Emeritus Norman Reid in 2013.
Currently, she is working as an assistant professor in one of the finest Institute of Pakistan, International Islamic University, Islamabad since 2008. Previously she has headed various educational institutions both from school and college cadre.

She is supervising numbers of post graduates in their research thesis including M.Phil. and Ph.D. Thesis as well. Her area of interest is curriculum and science education. She is an author of various international publications and has presented at various forums also.

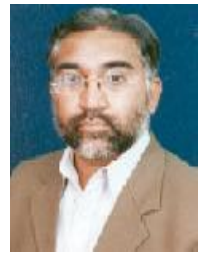

Hamid Hassan was born in Lahore the Capital of Punjab on April 16, 1967. He completed his Ph.D. in Education from the University of the Punjab, Lahore, Pakistan in 2007. Furthermore he did his Masters in Technology Education in 1995.

Currently, he is working as a lecturer in the Federal College of Education, Islamabad which is a post graduate teacher training institute catering the needs of both pre-service and In-service teachers' Education and training . He has received specialized trainings from Chiba University Japan, Plymouth University N.H. USA

$\mathrm{He}$ is supervising number of post graduate research students for their dissertations. His area of interest is curriculum, technical and vocational education, educational leadership and management. $\mathrm{He}$ is an author of various international publications. 